\title{
Doživljanje stresa in izgorelosti, povezanih z delom z učenci s posebnimi potrebami pri učiteljih v osnovni šoli
}

\author{
Katja Košir ${ }^{1}$, Marta Licardo ${ }^{1}$, Sara Tement ${ }^{2}$ in Katarina Habe \\ ${ }^{1}$ Oddelek za temeljne pedagoške predmete, Pedagoška fakulteta, Univerza v Mariboru \\ ${ }^{2}$ Oddelek za psihologijo, Filozofska fakulteta, Univerza v Mariboru
}

\begin{abstract}
Povzetek: Namen raziskave je bil preveriti napovedno vrednost nekaterih značilnosti delovnega mesta osnovnošolskih učiteljev za doživljanje poklicnega stresa in izgorelosti. Značilnosti delovnega mesta so bile v raziskavi opredeljene kot zahteve in viri, ki smo jih nadalje delile na splošne in na specifične, vezane na delo z učenci s posebnimi potrebami. Preverjale smo, ali spremenljivke, povezane $\mathrm{z}$ delom $\mathrm{z}$ učenci s posebnimi potrebami, pojasnijo dodaten delež variance $\mathrm{v}$ doživljanju stresa in izgorelosti, ki ga ni mogoče pojasniti s splošnimi značilnostmi delovnega mesta. V raziskavi so sodelovali osnovnošolski učitelji iz vseh dvanajstih regij v Sloveniji; število sodelujočih variira od 439 do 886 . Rezultati kažejo, da specifične značilnosti delovnega mesta samostojno napovedujejo pomemben del variance stresa, emocionalne izčrpanosti in depersonalizacije. Splošne delovne obremenitve in specifična delovna obremenjenost z učenci s posebnimi potrebami predstavljata najbolj stabilna napovednika vseh treh proučevanih kriterijev. Na osnovi ugotovitev predlagamo tudi nekatere ukrepe za zmanjšanje stopnje doživljanja stresa ter za učinkovitejše spoprijemanje z njim.
\end{abstract}

Ključne besede: učitelji, osnovne šole, stres, spoprijemanje, izgorelost, učenci s posebnimi potrebami

\section{Stres and burnout related to work with special education needs students in elementary school teachers}

\author{
Katja Košir ${ }^{1}$, Marta Licardo ${ }^{1}$, Sara Tement ${ }^{2}$ and Katarina Habe ${ }^{1}$ \\ ${ }^{1}$ Department of Basic Pedagogical Studies, Faculty of Education, University of Maribor, Slovenia \\ ${ }^{2}$ Department of Psychology, Faculty of Arts, University of Maribor, Slovenia
}

\begin{abstract}
The aim of the present study was to examine the predictive value of elementary school teachers' workplace characteristics on work stress and burnout. Workplace characteristics were defined as job demands and resources, which were further divided into general and specific, related to work with special education needs students. We examined whether variables related to work with special education needs students explained incremental variance in stress and burnout above and beyond general workplace characteristics. Elementary school teachers from all twelve regions of Slovenia ( $N$ ranges from 439 to 886 ) took part in the study. The results have shown that workplace characteristics independently predict a significant amount of variance in stress, emotional exhaustion and depersonalization among teachers. General job demands and specific demands related to special education needs students are the highest and most stable predictors of all three studied criteria. Based on our findings, we suggest several measures which can help to alleviate stress and foster efficient coping strategies.
\end{abstract}

Key words: teachers, elementary schools, stress, coping behavior, burnout, special education students

\footnotetext{
"Naslov/Address: doc. dr. Katja Košir, Pedagoška fakulteta Univerze v Mariboru, Oddelek za temeljne pedagoške predmete, Koroška cesta 160, 2000 Maribor, e-pošta: katja.kosir@um.si
}

Članek je licenciran pod pogoji Creative Commons Attribution 4.0 International licence. (CC-BY licenca). The article is licensed under a Creative Commons Attribution 4.0 International License (CC-BY license). 
Kljub temu, da večina učiteljev svoje delo dojema kot zadovoljujoče in izpolnjujoče, velja poučevanje za stresen poklic (Borg in Riding, 1991). Učitelji se pri svojem delu soočajo s stresorji na različnih nivojih, pri čemer različni avtorji kot tipične stresorje učiteljev najpogosteje navajajo dejavnike, ki izhajajo iz interakcije z učenci in starši, prevelike razrede, administrativne naloge, pomanjkanje opreme, hrup, sodelavce in sistem vodenja ter status poklica (za pregled raziskav glej npr. Slivar, 2013). V zadnjih desetletjih zahteve na delovnem mestu učitelja naraščajo, viri učiteljev za spoprijemanje z njimi pa se najverjetneje ne povečujejo sorazmerno s porastom zahtev (McCarthy in Lambert, 2006) ter so pretežno prepuščeni iniciativi posameznih učiteljev oziroma $\mathrm{v}$ najboljšem primeru šol. V pričujoči raziskavi smo želele preveriti, v kolikšni meri splošne značilnosti delovnega mesta ter specifične značilnosti delovnega mesta, vezane na delo $\mathrm{z}$ učenci $\mathrm{s}$ posebnimi potrebami (v nadaljevanju UPP), napovedujejo doživljanje stresa in izgorelosti pri učiteljih osnovne šole. Bolj specifično smo želele ugotoviti, ali je s specifičnimi značilnostmi delovnega mesta, vezanimi na delo z UPP, mogoče pojasniti še dodaten delež variance v doživljanju stresa in izgorelosti pri učiteljih, ki ga splošne delovne obremenitve ne pojasnjujejo. Na obeh ravneh - na ravni splošnih in na ravni specifičnih, na delo z UPP vezanih delovnih obremenitev - smo preverjale tako zahteve dela kot vire za spoprijemanje z njimi.

\section{Doživljanje stresa in izgorelosti pri učiteljih}

Stres je najpogosteje opredeljen kot skupek negativnih čustvenih odzivov, do katerih pride, kadar je posameznik izpostavljen dlje časa trajajočim in stopnjujočim se pritiskom, ki jih s svojimi strategijami spoprijemanja ne more več obvladovati (Kyriacou, 1987). Podobno Lazarus in Folkman (1984) stres opredeljujeta kot neravnovesje med zahtevami in viri, ki se pojavijo, ko zahteve presežejo posameznikovo zaznano sposobnost spoprijemanja $\mathrm{z}$ njimi. Tuje raziskave (zlasti raziskave, izvedene v ZDA), ki so preučevale doživljanje stresa, so izhajale predvsem iz problema visoke stopnje osipa in fluktuacije v učiteljskem poklicu; tako naj bi do petega leta delovne dobe učiteljski poklic zapustilo približno 40 \% učiteljev (Chang, 2009; Smith in Ingersoll, 2004). Raziskave, izvedene v tujini, kažejo, da je učiteljski poklic stresen tudi v primerjavi z drugimi poklicnimi skupinami (Stoeber in Rennert, 2008; Travers in Cooper, 1993). Poleg tega raziskave kažejo, da je višja stopnja doživljanja stresa značilna za ženske (Chaplain, 2008) in za učitelje začetnike (Regent, 2013; Yagil, 1998).

Slivar (2009) je na vzorcu slovenskih učiteljev osnovne in srednje šole ugotovil, da učitelji v osnovni in srednji šoli kot najbolj stresno okoliščino svojega dela dojemajo nesramno vedenje učencev do učiteljev. Poleg tega osnovnošolski učitelji kot stresne ocenjujejo predvsem okoliščine, povezane s komunikacijo s starši učencev, in nasilje med učenci. Srednješolski učitelji pa kot stresno ocenjujejo še nemotiviranost učencev za učenje, preveliko število učencev $\mathrm{v}$ razredu, neizvajanje sankcij proti kršiteljem šolskega reda na šoli in vodenje postopka za vzgojne ukrepe.

Doživljanje visoke stopnje dlje časa trajajočega stresa na delovnem mestu lahko vodi v izgorelost; gre za stanje, ko zahteve na delovnem mestu obremenijo ali presežejo posameznikove vire. Najpogosteje navedena in najvplivnejša opredelitev izgorelosti je še vedno opredelitev avtorice Maslach (Maslach, Schauferli in Leitner, 2001), ki izgorelost opredeljuje kot sindrom čustvene izčrpanosti, depersonalizacije in zmanjšanja osebnih dosežkov v poklicih, kjer gre za delo z ljudmi. Pri tem se čustvena izčrpanost nanaša na doživljanje preobremenjenosti in izčrpanosti ob emocionalnih zahtevah posameznikovega dela, depersonalizacija pa na distanciran in ciničen odnos do udeležencev, s katerimi delavec pri svojem delu vzpostavlja odnos. Zmanjšani dosežki se odražajo v posameznikovi samooceni, da ni več učinkovit pri svojem delu s strankami, pacienti ali učenci ter pri izpolnjevanju svojih delovnih nalog. Gre torej za upad v samooceni lastne strokovne učinkovitosti, pri čemer ta vidik $\mathrm{v}$ modelu izgorelosti ne predstavlja ločene dimenzije, saj je le $\mathrm{v}$ manjši meri povezan s prej omenjenima dimenzijama izgorelosti, ki predstavljata $\mathrm{v}$ modelu izgorelosti jedrni dimenziji, obenem pa se izmed vseh treh vidikov izgorelosti najšibkeje povezuje z drugimi s stresom povezanimi spremenljivkami (Lee in Ashforth, 1996). Čeprav je avtorica te opredelitve izgorelost omejila na poklice pomoči, pa sodobnejši avtorji (npr. Demerouti, Bakker, Nachreiner in Schaufeli, 2001) opozarjajo, da lahko do izgorelosti prihaja pri posameznikih v vseh poklicnih skupinah. Raziskave kažejo, da se splošne obremenitve na delovnem mestu, kot je na primer preobremenjenost z delom, v večji meri povezujejo s čustveno izčrpanostjo kot bolj specifične emocionalne zahteve delovnega mesta (npr. resnost težav udeležencev; glej npr. Schaufeli in Enzman, 1998).

Raziskave, ki so preučevale izgorelost pri učiteljih, so pokazale, da učitelji v primerjavi z drugimi poklicnimi skupinami poročajo o višji stopnji čustvene izčrpanosti in depersonalizacije, torej obeh jedrnih dimenzij izgorelosti (Maslach, Jackson in Leiter, 1996; Schaufeli in Enzmann, 1998). V Sloveniji tovrstnih primerjalnih raziskav nimamo, velja pa omeniti raziskavo avtorice Depolli Steiner (2011b), ki je preučevala izgorelost na vzorcu 242 učiteljev osnovne šole. Rezultati te raziskave so pokazali, da se pri slovenskih učiteljih izgorelost kaže predvsem z dvema neugodno izraženima dimenzijama: osebno izpolnitvijo, ki je bila neugodno izražena pri približno $60 \%$ udeležencev raziskave, in čustveno izčrpanostjo, ki je bila neugodno izražena pri približno $60 \%$ udeleženih učiteljev, medtem ko depersonalizacijo doživlja bistveno manjši delež učiteljev (približno $25 \%$ ).

\section{Stres in izgorelost učiteljev, povezana z delom $z$ učenci s posebnimi potrebami}

Razvoj inkluzivne prakse, ki zajema vključenost, sprejemanje, enakopravnost, spodbujanje in cenjenje učencev s posebnimi potrebami, je v veliki meri odvisen 
od uspešnega dela učiteljev $\mathrm{s}$ to populacijo učencev (Schmidt, 2001; Resman, 2003; Bela knjiga, 2011). Delo z učenci s posebnimi potrebami od učitelja zahteva posebne metode, strategije in oblike dela, dodatno usposobljenost, interdisciplinaren pristop in timsko delo (Beattie, Jordan in Algozzine, 2006). Učitelj se mora biti sposoben prilagajati specifičnim potrebam vsakega učenca (Kavkler in Magajna, 2008). Mnogi učenci s posebnimi potrebami imajo razen učnih težav tudi čustvene, vedenjske ali druge težave, ki spremljajo primarno motnjo. Sočasno pojavljanje več motenj pri enem učencu s posebnimi potrebami ni redek pojav (San Miguel, Forness in Kavale, 1996; DuPaul, Gormley in Laracy, 2013), kar lahko za učitelja predstavlja dodatno obremenitev pri delu. Raziskave na primer kažejo, da ima kar $46 \%$ mladostnikov s specifičnimi učnimi težavami tudi čustvene in vedenjske motnje (Lerner, 2003; Shoemaker, 1996). Učitelj mora biti večkrat zelo potrpežljiv, imeti strpen odnos do učenca, učenca vključevati v vse aktivnosti, ga učiti socialnih veščin ter zavestno prispevati $\mathrm{k}$ zmanjševanju stisk in frustracij. Obenem mora izvajati individualizacijo in diferenciacijo pouka za celoten razred, pripravljati dodatne didaktične pripomočke, skrbeti za izvedbo in evalvacijo individualiziranih programov, sklicevati sestanke strokovne skupine za individualiziran program učenca $\mathrm{s}$ posebnimi potrebami, sodelovati z zunanjimi institucijami, poročati o napredku učenca, aktivno sodelovati s starši, upoštevati vse prilagoditve pouka, ocenjevanja znanj itd. (Magajna idr., 2008, Beattie idr., 2006). Kar nekaj je dodatnih delovnih nalog, ki so potencialno lahko stresni dejavniki pri delu $\mathrm{z}$ UPP in $\mathrm{v}$ našem vsebinskem okviru tega prispevka predstavljajo specifične delovne obremenitve.

Pomanjkanje znanja in usposobljenosti slovenskih učiteljev za delo z UPP je pogosto slišano dejstvo, hkrati se soočamo s pomanjkanjem strokovnjakov posameznih strok (specialni in rehabilitacijski pedagogi, tiflopedagogi, logopedi, socialni pedagogi), zato pomoč UPP pri izvedbi ur dodatne strokovne pomoči večkrat nudijo drugi pedagoški delavci, med katerimi so tudi učitelji. Predmetni učitelji posameznih strok niso dovolj usposobljeni za izvajanje podpore in pomoči ter odpravljanje težav, saj so v mnogih predmetnikih posameznih študijskih smeri sicer znanja za delo z UPP vključena, vendar je vprašanje, ali v zadostni meri. Ponujeni programi usposabljanja za šolske kolektive ne omogočajo poglobljenega in strokovnega pristopa za delo z UPP in pogosto ne zadoščajo kriteriju strokovnosti (Kovšca in Barle Lakota, 2010).

V srednješolskem izobraževanju, kjer več kot $90 \%$ ur dodatne strokovne pomoči izvajajo učitelji, je situacija še nekoliko slabša (Opara idr., 2010). Pomanjkanje znanja učiteljev kot oviro za inkluzivno vzgojo in izobraževanje učencev s posebnimi potrebami poudarjajo tako učitelji kot specialni pedagogi. Učitelji navajajo, da v času študija niso pridobili dovolj znanja za delo z UPP, specialni pedagogi pa, da nimajo dovolj predmetnega znanja za različne predmete $\mathrm{v}$ različnih srednješolskih programih, da bi lahko dobro sodelovali s srednješolskimi učitelji (Kavkler idr., 2010).
Raziskava, opravljena v Sloveniji na vzorcu 1360 učiteljev slovenskih osnovnih šol (Schmidt in Čagran, 2011), je pokazala, da učitelji najpogosteje zaznavajo fizično izčrpanost, čustveno izčrpanost in stres, kadar imajo $\mathrm{v}$ razredu vključene učence $\mathrm{z}$ vedenjskimi in čustvenimi motnjami, najmanj pa, kadar so $\mathrm{v}$ razred vključeni gibalno ovirani učenci. Raziskava je sicer vključevala le štiri skupine UPP (učence s čustveno vedenjskimi motnjami, $\mathrm{z}$ mejnimi intelektualnimi sposobnostmi, s primanjkljaji na posameznih področjih učenja in gibalno ovirane). Druga raziskava (Pretnar, 2012), ki je zajemala 400 učiteljev v slovenskih šolah je pokazala, da učiteljem zmanjkuje časa za kvalitetno delo z UPP, pri delu se počutijo preobremenjene, hkrati pa se zavedajo vpliva svojega odnosa in stališč do UPP. Menijo tudi, da imajo učitelji v inkluzivnih razredih več dela kot ostali ter da za dodatno delo niso ustrezno nagrajeni.

Raziskave, izvedene $\mathrm{v}$ tujini $\mathrm{v}$ osemdesetih in devetdesetih letih preteklega stoletja, so pokazale, da učitelji niso v zadostni meri pripravljeni sprejeti učencev s posebnimi potrebami (glej npr. Horne in Ricciardo, 1988). To Avramidis, Bayliss in Burden (2000) pojasnjujejo $\mathrm{z}$ dejstvom, da je bila integracija $\mathrm{v}$ številnih državah uvedena »ad hoc«, brez sistematičnih modifikacij glede na šolsko organizacijo, strokovno usposobljenost učiteljev ali zagotovitev nadaljnjih virov. Informativni so tudi rezultati metaanalitične raziskave avtorjev Scruggsa in Mastropierija (1996), ki je vključevala 28 raziskav, izvedenih v letih od 1958 do 1995 in skupno 10560 učiteljev; rezultati so pokazali, da dve tretjini vseh v raziskavo vključenih učiteljev $\mathrm{v}$ splošnem podpirata koncept vključevanja UPP $\mathrm{v}$ razrede, nekaj manj pa jih je pripravljenih vpeljati postopke integracije $\mathrm{v}$ svojem razredu. Le manj kot tretjina vseh vključenih učiteljev je zaznavala, da imajo dovolj časa, spretnosti, usposobljenosti in drugih virov, ki so potrebni za vključevanje UPP v redne oddelke. Tudi raziskava Peklaj idr. (2009) izvedena na vzorcu slovenskih učiteljev, je pokazala, da med vsemi kompetencami učitelji najbolj potrebujejo dodatna znanja prepoznavanja in ravnanja $\mathrm{z}$ učenci s posebnimi potrebami, učenja učnih strategij ter strategij soočanja in ravnanja $z$ neustreznim in agresivnim vedenjem.

Delovno mesto učitelja se je torej zaradi procesov integracije in inkluzije $\mathrm{v}$ zadnjih nekaj desetletjih zagotovo spremenilo. Reforme šolskega sistema vzgoje in izobraževanja otrok s posebnimi potrebami v devetdesetih letih so pri nas prinesle precej sprememb. Vzpostavil se je zakonski okvir za izvedbo izobraževanja otrok s posebnimi potrebami $\mathrm{v}$ rednih programih, npr. uvedba programa s prilagojenim izvajanjem in dodatno strokovno pomočjo (ZUOPP, 2000, 2011; ZOŠ 1996, 2006; ZOFVI, 2007), razširila se je opredelitev skupin otrok s posebnimi potrebami, vzpostavila mobilna specialno pedagoška služba $\mathrm{v}$ vrtcih in šolah, vse več otrok s posebnimi potrebami se je usmerilo $\mathrm{v}$ redne programe osnovne šole, zlasti je poraslo število otrok s specifičnimi učnimi težavami itd. (Bela knjiga, 2011). Med ključne dejavnike, ki so pomembni za razvoj inkluzije, brez dvoma spada delo učitelja $\mathrm{v}$ razredu $\mathrm{z}$ učenci s posebnimi potrebami, 
podpora učitelju s strani šole, kompetentnost učitelja in celoten sistem strokovne podpore (Viola, 2008). Predvidevamo, da učitelji delo z UPP doživljajo kot stresno, saj omenjeni dejavniki za razvoj inkluzije niso vedno in povsod izpolnjeni. Do višje stopnje stresa in izgorelosti pri učiteljih lahko prihaja zaradi neustreznih stališč do inkluzije, neustreznih stališč do UPP, šibke strokovne usposobljenosti in znanja učiteljev, pomanjkanja drugih virov, obremenitve $\mathrm{z}$ zahtevami dela $\mathrm{v}$ inkluzivnih razredih, večji obremenitvi pri pripravi na pouk, dodatnih obremenitvah $\mathrm{z}$ dokumentacijo ter zaradi časovnih obremenitev (Beattie idr., 2006; Horne in Ricciardo, 1988; Kavkler idr., 2010; Kovšca in Barle Lakota, 2010; Scruggs in Mastropieri, 1996).

\section{Model zahtev in virov na delovnem mestu}

Značilnosti delovnega mesta imajo pomemben učinek na blagostanje zaposlenih in lahko v veliki meri določajo tako izgorelost kot zavzetost na delovnem mestu. Odnos med značilnostmi delovnega mesta in blagostanjem zaposlenih trenutno najbolje pojasnjuje model zahtev in virov na delovnem mestu (angl. job demands-resources model; Bakker in Demerouti, 2007; Bakker, Demerouti, De Boer in Schaufeli, 2003; Demerouti idr., 2001). Model predpostavlja, da je značilnosti delovnega mesta mogoče razdeliti $\mathrm{v}$ dve kategoriji - delovne zahteve in delovne vire - in da ti dve kategoriji značilnosti delovnega mesta napovedujeta različne s stresom povezane izide. Delovne zahteve se nanašajo na tiste fizične, psihološke, socialne ali organizacijske vidike dela, ki od posameznika zahtevajo stalna fizična in/ali psihološka prizadevanja in so povezane z določenimi fiziološkimi in/ali psihološkimi stroški (Demerouti idr., 2001). Gre za dejavnike, ki niso stresorji sami po sebi, lahko pa to postanejo v situacijah, ki zahtevajo visoko prizadevanje, da bi ohranili pričakovano raven izvedbe, in lahko vodijo v izgorelost. Delovni viri pa predstavljajo tiste fizične, psihološke, socialne ali organizacijske vidike dela, ki (1) lahko zmanjšajo delovne zahteve in z njimi povezane fiziološke ali psihološke stroške; (2) so posamezniku v pomoč pri doseganju delovnih ciljev in (3) spodbujajo osebnostno rast, učenje in razvoj. Model je dobro empirično podprt (Bakker, Demerouti in Euwema, 2005; Bakker in Demerouti, 2007), in sicer tudi pri poklicni skupini učiteljev (Hakanen, Bakker in Schauferli, 2006; Jepson in Forrest, 2006). Hakanen idr. (2006) so na velikem vzorcu finskih učiteljev potrdili predpostavke modela, da delovne zahteve napovedujejo izgorelost na delovnem mestru, delovni viri pa so napovedniki delovne zavzetosti.

\section{Namen raziskave}

V naši raziskavi smo preučevale nekatere značilnosti delovnega mesta osnovnošolskih učiteljev, ki so bile v dosedanjih raziskavah prepoznane kot pomembne zahteve in viri na delovnem mestu učitelja. Na ravni splošnih značilnosti delovnega mesta smo izmed delovnih zahtev vključile splošne delovne obremenitve (Borg in Riding, 1991; Burke in Greenglass, 1995; Depolli Steiner, 2011a), na ravni specifičnih zahtev delovnega mesta smo med delovne zahteve vključile delovno obremenitev z UPP (Darling-Hammond, 2001; Stempien in Loeb, 2002). Izmed delovnih virov smo na ravni splošnih značilnosti delovnega mesta vključile avtonomijo (Skaalvik in Skaalvik, 2009), oporo sodelavcev (Friedman, 1991; Skaalvik in Skaalvik, 2011) in oporo nadrejenih (Coladarci, 1992; Rosenholtz in Simpson, 1990; Skaalvik in Skaalvik, 2009 in 2011). Na ravni specifičnih značilnosti delovnega mesta, vezanih na delo z UPP, smo med delovne vire vključile zaznano lastno kompetentnost učiteljev pri delu z UPP (Larhoven, Munk, Lynch, Bosma in Rouse, 2007), zadovoljstvo učiteljev s splošnim sistemom strokovne podpore za UPP in oporo pri delu z UPP na šoli (Martinez, 2003).

Ključni namen raziskave je bil ugotoviti, ali je mogoče $\mathrm{z}$ vključitvijo spremenljivk, povezanih $\mathrm{z}$ delom z učenci s posebnimi potrebami, pojasniti dodaten delež variance $\mathrm{v}$ doživljanju stresa in izgorelosti pri učiteljih osnovne šole. Preverjale smo del modela zahtev in virov delovnega mesta. $\mathrm{V}$ terminologiji modela zahtev in virov na delovnem mestu bi torej lahko sklepali, da so zahteve dela z UPP večje od virov za delo s temi učenci, kar lahko predstavlja stresor, ki deluje ob vseh ostalih dejavnikih doživljanja stresa na delovnem mestu učitelja in ki še dodatno doprinese $\mathrm{k}$ doživljanju stresa in posledično izgorelosti pri učiteljih.

\section{Metoda}

\section{Udeleženci}

$\mathrm{V}$ raziskavi je sodelovalo skupno 886 učiteljic in učiteljev, od teh je bilo $90,6 \%$ žensk $(n=803)$ in 9,4 $\%$ moških $(n=83)$. Povprečna delovna doba učiteljev v vzorcu je bila 15,24 let $(S D=10,39)$, povprečna starost je bila 42,35 let $(S D=9,08)$. Povprečno število učencev s posebnimi potrebami, ki jih učitelji poučujejo, je bilo $5,17(S D=5,69 ; \min =0, \max =30)$, od teh je po mnenju učiteljev največ učencev s primanjkljaji na posameznih področjih učenja $(M=3,18, S D=3,55)$, najmanj pa slepih in slabovidnih učencev $(M=0,06 ; S D=0,28)$.

Sodelovali so učitelji iz vseh dvanajstih regij $\mathrm{v}$ Sloveniji. Iz Osrednjeslovenske regije je sodelovalo 34,0 \% učiteljev ( $n=301)$, iz Podravske regije 22,2 \% učiteljev $(n=197)$, iz Gorenjske regije $7,1 \%$ učiteljev $(n=63)$, iz Savinjske regije $7 \%$ učiteljev $(n=62)$, iz Pomurske regije $6,3 \%$ učiteljev $(n=56)$, iz Obalno-kraške regije 5,5\% učiteljev $(n=49)$, iz Zasavske regije $5 \%$ učiteljev $(n=44)$, iz Koroške regije 3,8 \% učiteljev $(n=34)$, iz Goriške regije $3,5 \%$ učiteljev $(n=31)$, iz JV Slovenije 2,3\% učiteljev $(n=20)$, iz Notranjsko-kraške regije $1,7 \%$ učiteljev ( $n$ $=15)$ in iz Spodnjeposavske regije 1,6\% učiteljev ( $n=$ 14). Vključeni so bili učitelji, ki so poučevali na razredni stopnji $(39,2 \%)$, na predmetni stopnji $(33,6 \%)$ ter na razredni in predmetni stopnji hkrati $(20,2 \%)$. 
Vsi učitelji niso izpolnili vseh vprašalnikov do konca, zato število sodelujočih za posamezne sklope variira, in sicer v razponu od 439 do 886 učiteljev. Podatki sodelujočih učiteljev, ki so izpolnili posamezne sklope vprašalnika, so razvidni v tabeli 1 . Ker težko upravičimo, da so manjkajoče vrednosti pri posameznih vprašalnikih nastale naključno, nismo uporabljali nobene strategije nadomeščanja manjkajočih vrednosti.

\section{Pripomočki}

Vprašalnik doživljanja stresa (Cohen, Kamark in Mermelstein, 1983) meri stopnjo zaznanega stresa in skupno vključuje 10 postavk. Gre za enodimenzionalni instrument, pri katerem udeleženci $\mathrm{s}$ pomočjo 5stopenjske odgovorne lestvice $(1$ - nikoli; 5 - zelo pogosto) ocenijo, kako pogosto so se počutili na določen način. Za razliko od originalne angleške različice, kjer se postavke navezujejo na obdobje enega meseca, so se pričujoči odgovori navezovali na obdobje zadnjega pol leta in na specifični stres v šolskem kontekstu. Avtor originala navaja zadovoljive koeficiente zanesljivosti (od 0,84 do 0,86). Številne študije potrjujejo tudi konstruktno veljavnost instrumenta (npr. Siqueira Reis, Ferreira Hino in Rodriguez Ã̃ez, 2010). Slovenski prevod je nastal z metodo dvojnega prevoda, pri kateri je psihologinja $\mathrm{s}$ tekočim znanjem angleškega jezika lestvico najprej prevedla v slovenščino, druga sodelavka pa je slovensko verzijo prevedla nazaj v angleščino. Morebitna pomenska neskladja med angleškim izvirnikom in angleškim prevodom smo popravili v slovenski različici.

Vprašalnik izgorelosti (Maslach Burnout Inventory - Educators Survey, Maslach, Jackson in Leiter, 1996; Depolli Steiner, 2011b) meri poklicno izgorelost, ki vključuje dimenzije emocionalne izčrpanosti, odtujenega odnosa do dela (tj. depersonalizacija) in zmanjšane osebne učinkovitosti. V polni verziji vprašalnik vključuje 22 trditev, ki jih udeleženci ocenjujejo s pomočjo 7-stopenjske lestvice pogostosti ( 0 - nikoli; 6 - vsak dan). V raziskavi smo uporabili zgolj dimenziji izčrpanost ( 9 postavk) in depersonalizacija (5 postavk), ki predstavljata temeljni dimenziji izgorelosti (npr. Demerouti idr., 2001). Po mnogih raziskavah sodeč je vprašalnik zadovoljivo zanesljiv in veljaven ter predstavlja najpogosteje uporabljeno mero izgorelosti (npr. Demerouti idr., 2001). Tudi slovenska verzija kaže zadovoljive psihometrične karakteristike koeficient notranje skladnosti za emocionalno izčrpanost znaša 0,88 , za depresonalizacijo pa 0,84 , ustrezna pa je tudi faktorska struktura vprašalnika (Depolli Steiner, 2010).

Vprašalnik delovnih zahtev in virov (Tement, Korunka in Pfifer, 2010; Tement in Korunka, 2013) je večdimenzionalni instrument, ki zajema delovne obremenitve (5 postavk), avtonomijo (3 postavke), raznolikost dela (3 postavke), oporo s strani sodelavcev (4 postavke) in nadrejenih (4 postavke). Lestvica delovnih zahtev je prevzeta po avtorjih Boyar, Carr, Mosley, Jr. in Carson (2007); ostale postavke pa so bile sestavljene po zgledu uveljavljenih obstoječih instrumentov (npr. Job Content Questionnaire; Karasek, Brisson, Kawakami, Houtman, Bongers in Amick, 2000). Vprašalnik vključuje trditve, vezane na omenjene značilnosti delovnega mesta; udeleženci jih ovrednotijo s pomočjo 5-stopenjske lestvice (1 - sploh se ne strinjam; 5 - popolnoma se strinjam). V preteklih raziskavah se je pokazalo, da ima vprašalnik zadovoljive merske značilnosti (od 0,79 do 0,89; Boyar idr., 2007; Tement idr., 2010). Po preteklih raziskavah sodeč ugodne merske značilnosti ogroža obratno vrednotena postavka pri raznolikosti delovnih nalog (Tement idr., 2010; Tement in Korunka, 2013). Iz tega razloga omenjene postavke v pričujoči študiji nismo uporabili.

Vprašalnik o specifičnih značilnostih delovnega mesta, vezanih na delo z UPP. Vprašalnik, s katerim smo zbrale podatke za analizo specifičnih značilnosti delovnega mesta vezane na delo z UPP, smo oblikovale za potrebe te raziskave. Vprašalnik zajema štiri dimenzije: delovna obremenitev z UPP (6 postavk), kompetentnost učitelja pri delu z UPP (4 postavk), zadovoljstvo učitelja s splošnim sistemom strokovne podpore za UPP (5 postavk) in opora pri delu z UPP na šoli (4 postavk). Vprašalnik vsebuje 5-stopenjsko ocenjevalno lestvico (1 - sploh se ne strinjam, 5 - popolnoma se strinjam). Trditve $\mathrm{v}$ dimenziji delovna obremenitev $\mathrm{z}$ UPP se nanašajo na obremenitve $\mathrm{z}$ dodatnim delom za priprave, časovne obremenitve, povezane s sestanki strokovnih timov za UPP, čas za urejanje in pisanje dokumentacije, obremenitve pri poučevanju, pritisk staršev, usklajevanje urnikov in (ne)ustrezno finančno ovrednotenje dela. Trditve, ki merijo dimenzijo kompetentnost učitelja pri delu z UPP, se nanašajo na učiteljevo zaznavo uspešnega premagovanja težav pri delu z UPP, uspešnega poučevanja, lastne usposobljenosti za tovrstno delo, avtonomnost pri delu, uspešnosti pri izvajanju prilagoditev ipd. Dimenzijo zadovoljstvo učitelja s splošnim sistemom strokovne podpore za UPP smo preverjale s trditvami, ki odražajo mnenja učiteljev glede ustreznega števila strokovnih kadrov, strokovne podpore zunanjih ustanov, podpore na šoli, števila ur dodatne strokovne pomoči in utečeno prakso nudenja pomoči UPP. Zadnja dimenzija, opora pri delu z UPP na šoli, pa zajema trditve, ki se nanašajo na interno šolsko delo pri delu z UPP, npr. podporo specialnega pedagoga na šoli, podporo vodstva šole, pravočasnost pri nudenju pomoči, ustrezno količino časa in pozornosti, namenjeno delu z UPP na šoli. O merskih značilnostih in faktorski strukturi vprašalnika poročamo v poglavju Rezultati.

\section{Postopek}

Baterijo vprašalnikov smo za reševanje pripravile v spletni obliki. Januarja 2013 smo vprašalnik poslale kontaktnim osebam na osnovnih šolah, ki so vprašalnik posredovale naprej vsem učiteljem na šoli. Vprašalnik je bil na spletu dostopen mesec in pol. Sodelujočim je bila zagotovljena anonimnost. 


\section{Rezultati}

\section{Uvodne analize}

Vprašalnik o specifičnih značilnostih delovnega mesta, vezanih na delo z UPP, je za potrebe te raziskave oblikovan instrument, ki na prvem mestu zahteva proučitev morebitne večfaktorske strukture. Vprašalnik smo torej validirale $\mathrm{z}$ eksploratorno faktorsko analizo (EFA), natančneje $\mathrm{z}$ uporabe metode glavnih osi. Ker smo predvidevale relativno soodvisnost med faktorji, smo uporabile poševnokotno Direct Oblimin rotacijo. Pregled asimetričnosti in sploščenosti postavk ni pokazal večjih odstopanj od normalne porazdelitve (najvišja vrednost pri asimetričnosti je bila 0,81 , pri sploščenosti pa -0,88). Število relevantnih faktorjev smo na prvem mestu določile prek vzporedne analize, ki se je pokazala kot ustreznejša metoda za določanje števila faktorjev $\mathrm{v}$ primerjavi s Kaiser-Guttmanovim kriterijem (Hayton, Allen \& Scarpello, 2004). Z omenjenim pristopom smo ugotovile, da štiri lastne vrednosti presegajo naključno generirane vrednosti, pridobljene prek vzporedne analize. Na podlagi tega smo zaključile, da štirifaktorska rešitev predstavlja najbolj smiselno strukturo, kar smo upoštevali tudi pri nadaljnji EFA analizi. Prvi faktor smo poimenovale Zadovoljstvo učiteljev s splošnim sistemom strokovne podpore (lastna vrednost 7,24) in pojasnjuje 24,97\% variance. Drugi faktor Delovna obremenitev z UPP (lastna vrednost 3,32) pojasnjuje 11,44\% variance. Tretji faktor je poimenovan Zaznana lastna kompetentnost pri delu $\mathrm{z}$ UPP (lastna vrednost 1,69) in pojasnjuje 5,83\% variance, četrti - Opora pri delu z UPP na šoli (lastna vrednost 1,42 ) pa $4,98 \%$ variance. S kombinacijo vseh faktorjev je torej pojasnjene 47,12\% variance. Od izvorno 29 postavk smo končno verzijo vprašalnika skrčile na 19 postavk; 10 izločenih postavk ni dosegalo ustrezno visoke nasičenosti s katerimkoli od 4 faktorjev (uporabljen kriterij je bil $0,40)$, ni odražalo ustrezne vsebinske veljavnosti ali pa ni bilo nasičenih zgolj z enim faktorjem. Nasičenosti postavk v končni verziji ocenjujemo kot ustrezne, opozoriti pa bi želele na dve postavki z nekoliko nižjo nasičenostjo, ki se umeščata v četrti faktor. Postavke na vprašalniku, končne nasičenosti in korelacije med faktorji so prikazane $\mathrm{v}$ prilogi (tabeli 4 in 5).

V slovenskem okolju je bil prvič uporabljen tudi Vprašalnik doživljanja stresa (Cohen idr. 1983). Čeprav je vprašalnik v preteklosti že mnogokrat apliciran (npr. Siqueira Reis idr., 2010), obstajajo določene nejasnosti glede njegove faktorske strukture. Večina avtorjev ugotavlja dvofaktorsko strukturo (prvi faktor-doživljanje stresa, drugi faktor - spoprijemanje s stresom), vendar pa zaključuje, da najverjetneje obstaja hierarhična faktorska struktura in en nadredni faktor drugega reda. $\mathrm{Z}$ namenom preverjanja veljavnosti vprašalnika smo opravile več konfirmatornih faktorskih analiz $\mathrm{v}$ programu AMOS. Prileganje eno-faktorskega modela $\left(\chi^{2}(35)=408,65\right.$; GFI $=0,86 ; C F I=0,88 ; R M S E A=0,13)$, pri katerem so vse postavke nasičene $\mathrm{z}$ enim faktorjem, je bilo neprimerno in slabše (hi-kvadrat test razlik: $\Delta \chi^{2}(1)=225,68, p<0,001$ ) kot prileganje dvofaktorskega modela $\left(\chi^{2}(34)=182,98\right.$; $G F I=0,94 ; C F I=0,95 ;$ RMSEA $=0,085)$. Prileganje dvofaktorskega modela je na meji sprejemljivega, ob dodatku ene korelacije med napakami pri dveh pomensko zelo sorodnih postavkah pa se model izboljša $\left(\chi^{2}(33)=\right.$ $151,82 ; G F I=0,95 ; C F I=0,96 ; R M S E A=0,077)$. Faktorja drugega reda zaradi zgolj dveh faktorjev prvega reda kot indikatorjev ni bilo mogoče ustrezno specificirati (Byrne, 2001), je pa na podlagi visoke korelacije med obema faktorjema $(0,77)$ mogoče sklepati na močno pomensko prekrivanje obeh faktorjev. Iz tega razloga in hkrati skladno s preteklo literaturo (npr. Morgan, Umberson \& Hertzog, 2013) smo v nadaljnjih analizah zaznan stres obravnavale kot enodimenzionalni koncept.

\section{Opisne statistike}

V nadaljevanju (tabela 1) so prikazane opisne statistike za vse $\mathrm{v}$ nadaljnje analize vključene spremenljivke, korelacije med spremenljivkami in koeficienti notranje skladnosti. Pregled Pearsonovih koeficientov korelacij iz tabele 1 kaže, da vsi proučevani konstrukti korelirajo v pričakovani smeri. Znotraj skupine spremenljivk, vezanih na značilnosti delovnega mesta, so delovne zahteve relativno nepovezane $\mathrm{z}$ delovnimi viri. Po drugi strani pa splošne delovne obremenitve korelirajo pozitivno $\mathrm{z}$ doživljanjem stresa ter obema vidikoma izgorelosti (tj. emocionalna izčrpanost, depersonalizacija). Korelacije je mogoče interpretirati kot nizke do zmerno visoke. Avtonomija, opora sodelavcev in opora nadrejenih medsebojno pozitivno korelirajo. Hkratipa so vse omenjene spremenljivke negativno povezane s stresom, emocionalno izčrpanostjo in depersonalizacijo. Ponovno so korelacije nizke in zmerno visoke. Podobne povezave je mogoče zaslediti tudi pri specifičnih značilnostih delovnega mesta, vezanih na delo z UPP. Delovna obremenitev z UPP se negativno povezuje $s$ splošnimi in na delo $\mathrm{z}$ UPP vezanimi delovnimi viri ter je obenem pozitivno povezana s stresom in obema vidikoma izgorelosti. Vsi trije proučevani delovni viri, vezani na delo z UPP kompetentnost učitelja pri delu z UPP, zadovoljstvo učitelja s splošnim sistemom strokovne podpore za UPP in opora pri delu z UPP na šoli - medsebojno pozitivno korelirajo, hkrati pa so statistično pomembno negativno povezani s stresom, emocionalno izčrpanostjo in depersonalizacijo. Spremenljivki spol in starost sta relativno nepovezani $\mathrm{z}$ vsemi proučevanimi konstrukti, vezanimi na značilnosti delovnega okolja ter na morebitne škodljive posledice (stres, izgorelost). Izjema je povezava med starostjo in stresom, ki je nizka in negativna.

Pregled koeficientov zanesljivosti (določenih kot notranja skladnost) kaže, da so vsi koncepti zadovoljivo zanesljivi, saj večinoma presegajo priporočene vrednosti Cronbachovega alfa koeficienta (tj., .70). Nekoliko nižji Cronbachov alfa koeficient je mogoče opaziti zgolj pri spremenljivki opora pri delu z UPP na šoli. Kljub temu je koeficient takšne višine, ki je po mnenju nekaterih avtorjev še na meji sprejemljivega (npr. DeVellis, 2003). 


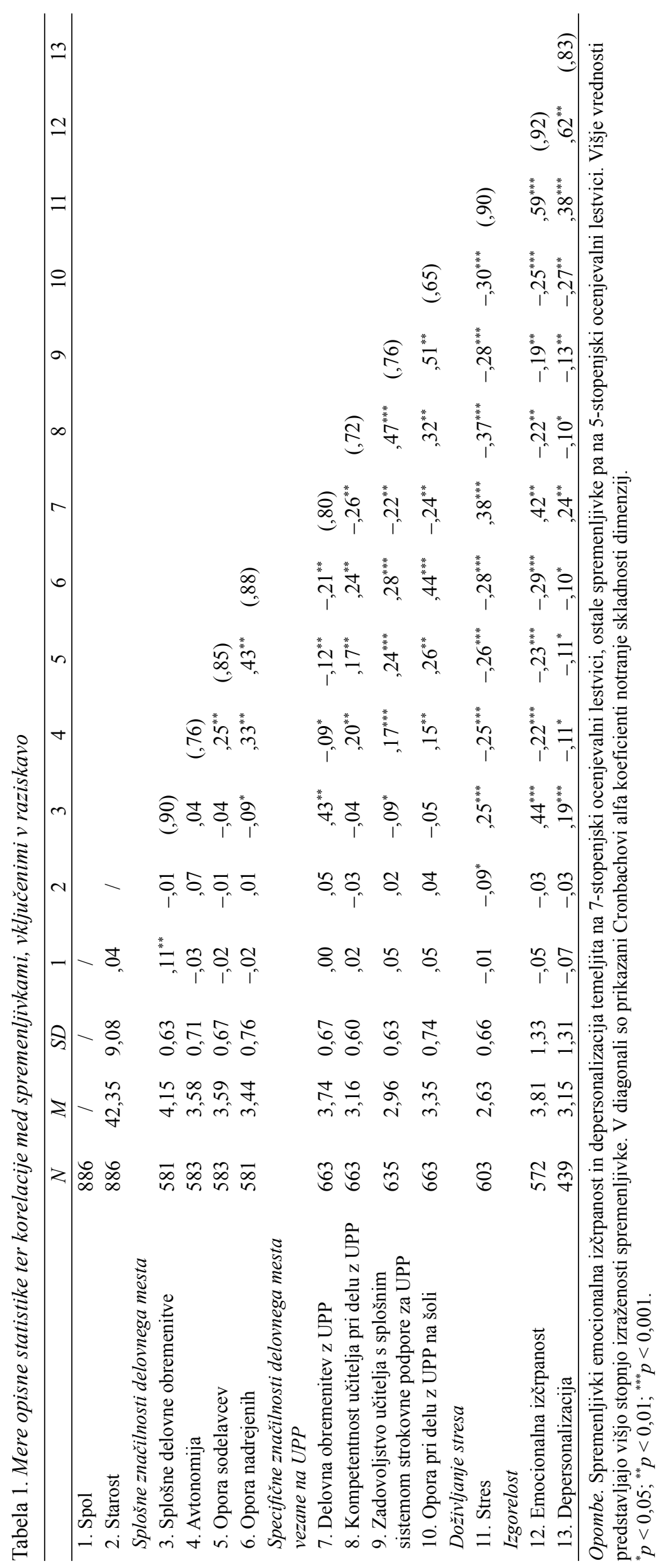


Tabela 2. Ocene regresijskih parametrov pri napovedovanju stresa pri učiteljih

\begin{tabular}{|c|c|c|c|c|c|c|}
\hline & \multicolumn{6}{|c|}{ Stres $(N=581)$} \\
\hline & \multicolumn{2}{|c|}{ Model 1} & \multicolumn{2}{|c|}{ Model 2} & \multicolumn{2}{|c|}{ Model 3} \\
\hline & $B$ & $\beta$ & $B$ & $\beta$ & $B$ & $\beta$ \\
\hline \multicolumn{7}{|l|}{ Korak 1: Kontrolne spremenljivke } \\
\hline Spol & $-0,02$ &,- 01 & $-0,11$ &,- 05 & $-0,03$ &,- 01 \\
\hline Starost & $-0,01$ &,$- 08^{*}$ & $-0,01$ &,- 07 & $-0,01$ &,- 08 \\
\hline$\Delta R^{2}$ & & 0,01 & & & & \\
\hline \multicolumn{7}{|l|}{$\begin{array}{l}\text { Korak 2: Splošne značilnosti delovnega } \\
\text { mesta }\end{array}$} \\
\hline Splošne delovne obremenitve & & & 0,25 &, $24^{* * *}$ & 0,16 & $15^{* *}$ \\
\hline Avtonomija & & & $-0,17$ &,$- 18^{* * *}$ & $-0,13$ &,$- 14^{* * *}$ \\
\hline Opora sodelavcev & & & $-0,15$ &,$- 15^{* * *}$ & $-0,12$ &,$- 12^{* *}$ \\
\hline Opora nadrejenih & & & $-0,12$ &,$- 14^{* *}$ & $-0,02$ &,- 02 \\
\hline$\Delta R^{2}$ & & & &, $18^{* * *}$ & & \\
\hline \multicolumn{7}{|l|}{$\begin{array}{l}\text { Korak 3: Specifične značilnosti delovnega } \\
\text { mesta vezane na UPP }\end{array}$} \\
\hline Delovna obremenitev z UPP & & & & & 0,18 & $18^{* * *}$ \\
\hline Kompetentnost učitelja pri delu z UPP & & & & & $-0,26$ &,$- 23^{* * *}$ \\
\hline $\begin{array}{l}\text { Zadovoljstvo s splošnim sistemom } \\
\text { strokovne podpore za UPP }\end{array}$ & & & & & 0,01 &, 01 \\
\hline Opora pri delu z UPP na šoli & & & & & $-0,12$ &,$- 12^{* *}$ \\
\hline$\Delta R^{2}$ & & & & & & $12^{* * *}$ \\
\hline$R^{2}$ & \multicolumn{2}{|l|}{, 01} & \multicolumn{2}{|c|}{, $19^{* * *}$} & \multicolumn{2}{|c|}{, $31^{* * *}$} \\
\hline$F$ za spremembo v $R^{2}$ & \multicolumn{2}{|l|}{2,02} & \multicolumn{2}{|c|}{$21,93^{* * *}$} & \multicolumn{2}{|c|}{$25,28^{* * *}$} \\
\hline
\end{tabular}

\section{Napovedniki stresa in izgorelosti}

Preliminarne analize, vezane na predpostavke za uporabo multiple regresije kot analitičnega postopka, so pokazale, da so potrebni pogoji pri napovedovanju vseh treh kriterijev (stres, izčrpanost in depersonalizacija) izpolnjeni. $\mathrm{Na}$ podlagi povezav med posameznimi napovedniki in prek indikatorjev VIF (iz angl. variance inflation factor) lahko sklepamo, da multikolinearnost $\mathrm{v}$ naših podatkih ne predstavlja večjega problema. Podobno lahko zatrdimo za obstoj t.i. vplivnih točk, ki bi sicer lahko popačile regresijski model (npr. najvišja Cookova razdalja pri napovedovanju stresa je znašala 0,04 , pri napovedovanju izčrpanosti 0,04 , pri depersonalizaciji pa 0,06). Pregled regresijskih predpostavk je nadalje pokazal, da z regresijskimi modeli pri napovedovanju stresa, izčrpanosti in depersonalizacije ne kršimo bistveno predpostavk homoscedastičnosti, linearnosti in približno normalne porazdelitve rezidualov (vsi standardizirani reziduali so se gibali v obsegu od -2,92 do 3,26 za stres, od $-2,15$ do 3,68 za izčrpanost, od -1,6 1 do 3,85 za depersonalizacijo). Na podlagi navedenega lahko upravičeno sklepamo, da so vsi trije regresijski modeli veljavni.

Rezultati hierarhične regresijske analize $\mathrm{z}$ metodo vključitve (iz angl. enter), prikazani $\mathrm{v}$ tabelah 2 in 3, prikazujejo, da tako med splošnimi značilnostmi delovnega mesta kot med specifičnimi značilnostmi dela z UPP najdemo pomembne napovednike stresa in obeh dimenzij izgorelosti (izčrpanosti in depersonalizacije). Pri vseh kriterijih smo v model najprej vključile kontrolne spremenljivke (tj. spol, starost), nato splošne značilnosti delovnega mesta, zatem pa $v$ tretjem koraku še specifične značilnosti delovnega mesta, vezane na delo z UPP. Pri napovedovanju stresa kontrolne spremenljivke (dodane $\mathrm{v}$ prvem koraku) ne pojasnijo statistično pomembnega deleža variance v kriteriju (skupno $1 \%$ ).

Kot je prikazano v tabeli 2, je od obeh kontrolnih spremenljivk zgolj starost pomemben napovednik stresa, pri čemer je smer povezanosti negativna, moč povezanosti pa šibka. Z drugimi besedami, z naraščajočo starostjo učiteljev se stopnja stresa znižuje. Splošne značilnosti delovnega mesta, dodane $\mathrm{v}$ drugem koraku, skupno pojasnijo statistično pomemben delež variance v kriteriju (18\%). Pregled standardiziranih regresijskih uteži kaže, da vsaka posamezna značilnost delovnega mesta statistično pomembno napoveduje stres. Pri splošnih delovnih obremenitvah je smer povezave pozitivna, medtem ko je pri t.i. delovnih virih smer povezave negativna. $\mathrm{Z}$ naraščajočo avtonomijo, oporo sodelavcev in nadrejenih stopnja stresa upada. Moč vseh povezanosti je šibka. Specifične spremenljivke delovnega mesta, vključene $\mathrm{v}$ model $\mathrm{v}$ tretjem koraku, pojasnjujejo dodatnih $12 \%$ variance v kriteriju. $Z$ izjemo spremenljivke zadovoljstvo učitelja s splošnim sistemom strokovne podpore za UPP so vsi kriteriji statistično pomembno povezani s stresom. Smer povezave je pri delovnih obremenitvah z UPP pozitivna, pri kompetentnosti učitelja pri delu z UPP ter 


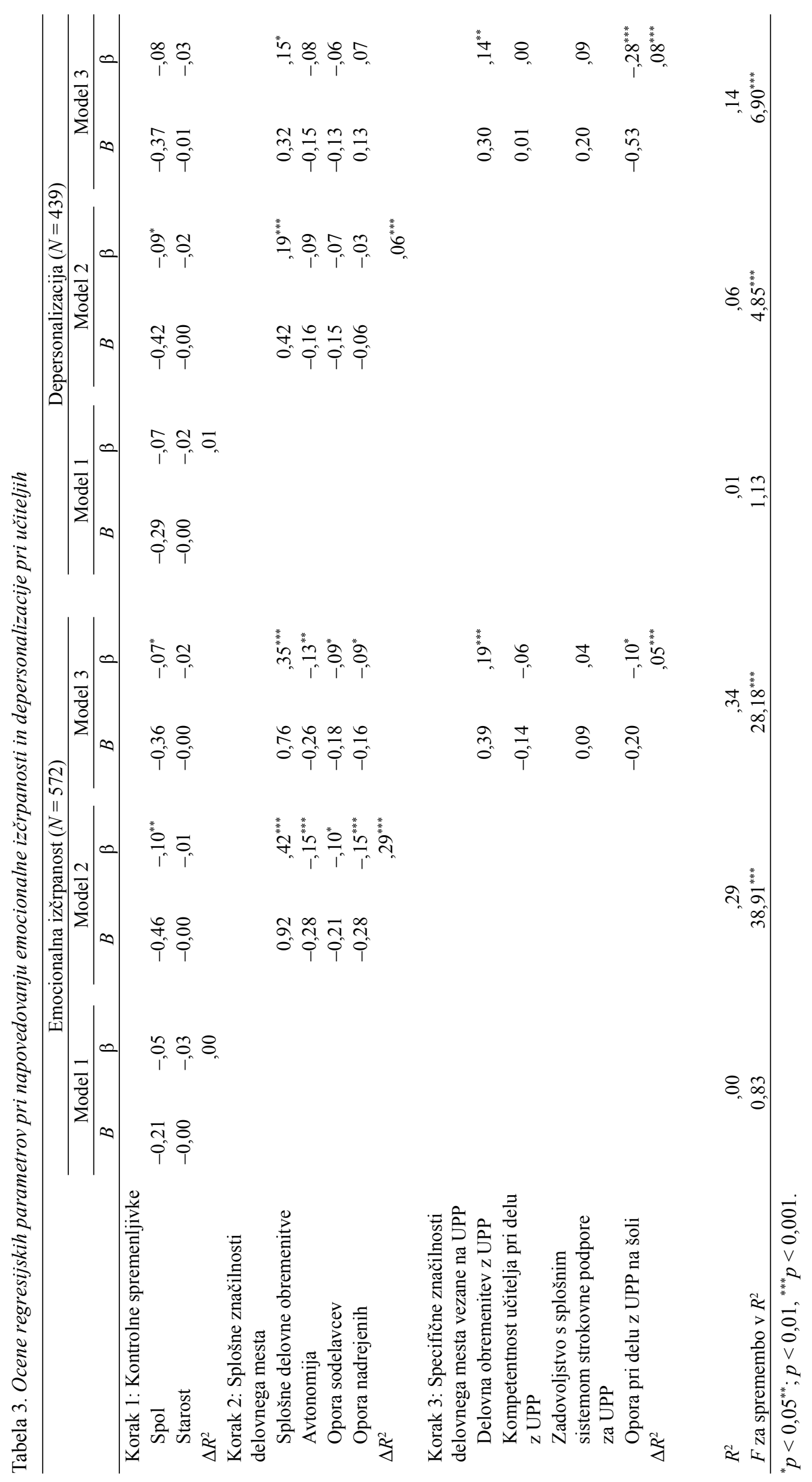


opori pri delu z UPP na šoli je smer povezave negativna. Moč povezanosti pri vseh napovednikih je šibka. Povedano drugače, višja kot je delovna obremenjenost z UPP, višja je stopnja stresa. Višja kot je kompetentnost pri delu z UPP in opora pri delu z UPP na šoli, nižja je stopnja stresa. Kljub temu, da so specifične spremenljivke delovnega mesta, vezane na UPP, pomembni napovedniki stresa, je stopnja splošnih delovnih obremenitev najpomembnejši napovednik stresa.

Podoben vzorec povezav med napovedniki in kriteriji lahko, $\mathrm{z}$ izjemo nekaterih spremenljivk, zasledimo tudi pri napovedovanju emocionalne izčrpanosti in depersonalizacije (tabela 3).

Pri napovedovanju emocionalne izčrpanosti kontrolne spremenljivke ne pojasnijo statistično pomembnega deleža variance v kriteriju, prav tako statistične pomembnosti ne dosega noben izmed obeh napovednikov v tem sklopu. Po drugi strani pa splošne značilnosti delovnega mesta pojasnjujejo kar 29 \% variance v kriteriju. Regresijske uteži vseh napovednikov v tem sklopu so tudi statistično značilne. Podobno kot pri stresu, so delovne obremenitve pozitivno povezane $\mathrm{Z}$ emocionalno izčrpanostjo, pri delovnih virih ( $\mathrm{tj}$. avtonomiji, opori sodelavcev, opori nadrejenih) pa je mogoče opaziti negativno povezavo. $\mathrm{Z}$ izjemo napovednika splošne delovne obremenitve, pri katerem je standardiziran regresijski nagib mogoče interpretirati kot zmerno visok, je moč vseh povezav šibka. Specifične značilnosti dela z UPP pojasnijo zgolj dodatnih $5 \%$ variance, pri čemer je zgolj spremenljivka delovna obremenitev z UPP statistično pomemben napovednik izčrpanosti. Višja stopnja delovne obremenjenosti $\mathrm{Z}$ UPP, podobno kot pri stresu, pomeni tudi višjo stopnjo emocionalne izčrpanosti. Opora pri delu z UPP na šoli se negativno povezuje s stopnjo emocionalne izčrpanosti, druga dva napovednika, ki jih $\mathrm{v}$ tem sklopu uvrščamo med delovne vire (kompetentnost učitelja pri delu z UPP in sistem strokovne podpore za UPP), nista pomembno povezani $\mathrm{z}$ emocionalno izčrpanostjo učitelja.

Pri napovedovanju depersonalizacije kontrolne spremenljivke ponovno ne pojasnijo statistično pomembnega deleža variance. $\mathrm{Na}$ podlagi regresijskih uteži lahko zaključimo, da tako spol kot starost nista povezana $\mathrm{z}$ depersonalizacijo. Od splošnih značilnosti delovnega mesta, dodanih $\mathrm{v}$ drugem regresijskem koraku, je zgolj spremenljivka splošne delovne obremenitve statistično pomemben napovednik depersonalizacije. Smer povezave pa je, podobno kot pri drugih dveh napovednikih, pozitivna. Splošne značilnosti delovnega mesta pri napovedovanju depersonalizacije pojasnijo zgolj dodatnih $6 \%$ variance. Večji delež variance v primeru depersonalizacije pojasnijo specifične značilnosti dela z UPP (8 \%). Ponovno je ocena obremenjenosti z UPP statistično značilno pozitivno povezana $\mathrm{s}$ kriterijem. Dodatno pa pomemben napovednik predstavlja še opora pri delu z UPP na šoli. V primeru boljše opore pri delu $\mathrm{z}$ UPP na šoli je stopnja depersonalizacije nižja, v primeru višje delovne obremenitve učitelja $\mathrm{z}$ UPP je stopnja depersonalizacije višja. Moč vseh povezav napovednikov $\mathrm{z}$ depersonalizacijo je ponovno mogoče označiti kot šibko.

V splošni primerjavi napovednikov lahko rečemo, da so splošne delovne obremenitve najpomembnejši napovednik izčrpanosti, pri napovedovanju depersonalizacije pa je najpomembnejši napovednik opora pri delu z UPP na šoli. Nadalje lahko sklenemo, da sta splošne delovne obremenitve in specifična delovna obremenjenost z UPP najbolj stabilna napovednika vseh treh proučevanih kriterijev. Povezave drugih splošnih ali specifičnih značilnosti delovnega mesta s kriteriji med samimi kriteriji precej variirajo.

\section{Razprava}

$\mathrm{V}$ raziskavi smo preverjale napovedno vrednost nekaterih splošnih in specifičnih, na delo z UPP vezanih stresorjev za doživljanje stresa in izgorelosti pri učiteljih osnovne šole. Rezultati raziskave so pokazali, da predstavlja spremenljivka stopnja splošnih delovnih obremenitev najpomembnejši dejavnik stresa in emocionalne izčrpanosti: učitelji, ki pri svojem delu zaznavajo višjo stopnjo delovnih obremenitev, poročajo o višji stopnji doživljanja stresa. Omenjeno je razvidno iz koraka, v katerem je bila spremenljivka dodana $\mathrm{v}$ regresijski model, višina regresijskih nagibov pa v zadnjem koraku sicer upade (zaradi korelacij z drugimi prediktorji). Splošni delovni viri (avtonomija, opora sodelavcev ter nadrejenih) se negativno povezujejo s stopnjo doživljanja stresa in emocionalne izčrpanosti: učitelji, ki poročajo o višji stopnji avtonomije, opore sodelavcev in nadrejenih v svojem delovnem okolju, doživljajo manj stresa in emocionalne izčrpanosti. Podoben trend povezanosti s splošnimi značilnostmi delovnega mesta se kaže tudi pri depersonalizaciji, vendar je odnos šibkejši in statistično pomemben le za napovednik splošne delovne obremenitve. Te ugotovitve potrjujejo predpostavke modela virov in zahtev na delovnem mestu, saj so $\mathrm{v}$ raziskavo vključene delovne obremenitve pozitivno, delovni viri pa negativno povezani $\mathrm{z}$ doživljanjem stresa in izgorelosti pri učiteljih. Prav tako so rezultati naše raziskave skladni $\mathrm{z}$ ugotovitvami nekaterih drugih raziskav, ki so preučevale vlogo posameznih delovnih obremenitev in virov (npr. Coladarci, 1992; Friedman, 1991; Rosenholtz in Simpson, 1990; Skaalvik in Skaalvik, 2009 in 2011). Splošne značilnosti delovnega mesta najbolje pojasnjujejo doživljanje emocionalne izčrpanosti (29\% pojasnjene variance), sledi doživljanje stresa (19 \%), najmanj učinkovito pa je mogoče z njimi pojasniti depersonalizacijo (6\% pojasnjene variance).

Naše osrednje raziskovalno vprašanje se je nanašalo na vlogo specifičnih značilnosti delovnega mesta, vezanih na delo z UPP. Preverjale smo, ali lahko z vključitvijo zahtev in virov, povezanih $\mathrm{z}$ delom $\mathrm{z}$ UPP, pojasnimo dodaten delež variance $\mathrm{v}$ doživljanju stresa in izgorelosti pri učiteljih, 
ki ga ni mogoče pojasniti s splošnimi značilnostmi delovnega mesta. Raziskave v slovenskih osnovnih šolah namreč kažejo, da učitelji pri delu z UPP poročajo o večjih delovnih obremenitvah, fizični izčrpanosti, čustveni izčrpanosti, preobremenjenosti in doživljanju stresa (Pretnar, 2012; Schmidt in Čagran, 2011). Rezultati naše raziskave so pokazali, da specifične, na delo z UPP vezane značilnosti delovnega mesta statistično pomembno prispevajo k doživljanja stresa in izgorelosti pri učiteljih. Opora pri delu z UPP na šoli predstavlja najpomembnejši napovednik depersonalizacije pri učiteljih, ki jo pomembno napoveduje tudi delovna obremenitev z UPP: učitelji, ki poročajo o nižji stopnji opore pri delu z UPP na šoli in višji stopnji delovne obremenitve $z$ UPP, imajo višjo stopnjo depersonalizacije. Delovna obremenitev $\mathrm{Z}$ UPP napoveduje tudi doživljanje stresa in emocionalne izčrpanosti učiteljev: učitelji, ki poročajo o višji stopnji obremenitve z UPP, doživljajo več stresa in so bolj emocionalno izčrpani. Doživljanje stresa napovedujeta tudi kompetentnost učitelja pri delu z UPP in opora pri delu z UPP na šoli: učitelji, ki se zaznavajo kot kompetentnejše pri delu z UPP in ki zaznavajo na šoli višjo stopnjo opore pri delu s temi učenci, poročajo o nižji stopnji stresa. Izmed specifičnih značilnosti delovnega mesta, vezanih na UPP, le zadovoljstvo s splošnim sistemom strokovne podpore za UPP ne napoveduje nobene izmed kriterijskih spremenljivk. Dodana pojasnjevalna vrednost vključitve specifičnih značilnosti delovnega mesta, vezanih na UPP, je največja za kriterijsko spremenljivko doživljanje stresa, kjer te spremenljivke pojasnjujejo dodatnih $12 \%$ variance. Za obe dimenziji izgorelosti je ta delež nekoliko nižji: $5 \%$ za emocionalno izčrpanost in 8 \% za depersonalizacijo.

Starost in spol učiteljev se nista pokazala kot pomembna dejavnika doživljanja stresa in izgorelosti pri učiteljih. Izjema je odnos med starostjo in doživljanjem stresa: z naraščajočo starostjo učiteljev se stopnja stresa znižuje, vendar pa je delež s starostjo pojasnjene variance $\mathrm{v}$ doživljanju stresa zelo majhen.

Kot najbolj stabilna dejavnika doživljanja stresa in izgorelosti učiteljev sta se torej pokazali dve zahtevi delovnega mesta: splošna delovna obremenitev in specifična obremenitev z delom z UPP. Učitelji z višjo stopnjo doživljanja stresa in izgorelosti torej zaznavajo višjo stopnjo delovne obremenjenosti. Pri tem bi bilo zanimivo preveriti, ali gre za dejansko višjo stopnjo obremenjenosti ali jo učitelji le tako zaznavajo. Od odgovora na to vprašanje so namreč deloma odvisni tudi ukrepi, ki bi pripomogli k znižanju stopnje doživljanja stresa. V kolikor gre za neenakomerno obremenjenost učiteljev znotraj posameznih šol, bi bilo s strani vodstva smiselno ukrepati $\mathrm{v}$ smeri bolj uravnotežene delovne obremenitve znotraj kolektiva. Za zmanjšanje dejanske delovne obremenjenosti učiteljev bi bilo smiselno ukrepati tudi v smeri optimizacije dokumentacije, povezane z delom z UPP ter sprejetje različnih ukrepov, ki bi predstavljali višjo stopnjo opore učitelju pri delu z UPP. V primeru, da učitelji svojo delovno obremenjenost neustrezno visoko zaznavajo, bi jim bilo smiselno ponuditi možnost, da ob podpori strokovnjaka (npr. v kontekstu supervizije) preokvirijo svoje dojemanje ali da učitelju, ki v enem razredu poučuje večje število UPP, pomaga drugi učitelj oz. strokovni delavec (npr. inkluzivni pedagog).

Ob dejstvu, da je določena mera delovnih obremenitev neizogibna, pa bi bilo smiselno iskati načine za povečevanje virov za spoprijemanje $\mathrm{z}$ delovnimi obremenitvami, torej iskati sistemske možnosti za učinkovitejše spoprijemanje učiteljev z delovnimi zahtevami, zlasti pri delu z UPP. V zvezi s tem bi bilo smiselno na šolah postopno namenjati več sredstev in uvajati več orodij profesionalnega razvoja učiteljev, in sicer tako izobraževanja o posebnostih različnih skupin UPP, ki bi učiteljem omogočala boljše razumevanje teh učencev in bolj vešče delo z njimi, kot tudi več organiziranih priložnosti, da učitelji v varnem okolju odkrito spregovorijo o lastnih stiskah, ki jih pri delu v sodobnih izjemno heterogenih razredih skoraj neizogibno vsaj občasno doživljajo. Slednje bi bilo smiselno organizirati predvsem v kontekstu supervizije (glej npr. Kobolt in Žorga, 2013) ali kolegialnega coachinga (glej Rutar Ilc, Tacer in Žarkovič Adlešič, 2014). K bolj konstruktivnemu in reflektiranemu načinu spoprijemanja s stresom pa bi najverjetneje prispevalo tudi postopno spreminjanje šolske klime od izrazito storilnostne, kjer napake veljajo za odraz nekompetentnosti posameznika, v smer kulture dobre skupnosti, kjer so napake (tako učiteljev kot učencev) pojmovane kot del učnega procesa (Ryan, Conell in Deci, 1985; Reeve, 2002; Quint, Bloom, Black, Stephens in Akey, 2005). Menimo, da bi s tovrstnimi ukrepi postopno prispevali $\mathrm{k}$ zmanjšanju izgorelosti pri učiteljih ter k zviševanju vidika, ki ga nekateri avtorji (npr. Maslach idr., 2001) pojmujejo kot nasprotni pol izgorelosti - to je zavzetosti pri delu.

\section{Omejitve raziskave in smernice za nadaljnje raziskovanje}

Posplošljivost rezultatov raziskave je omejena zaradi nenaključnega vzorčenja; vprašalnik s prošnjo za sodelovanje učiteljev v raziskavi je bil sicer poslan na vse slovenske šole, vendar pa se je povabilu odzval le delež učiteljev. Glede na značilnosti preučevanega področja lahko v zvezi s tem predpostavimo pristranskost podatkov $\mathrm{v}$ pozitivno smer: tisti, ki doživljajo največ stresa in izgorelosti, se za sodelovanje $\mathrm{v}$ raziskavi zaradi visoke delovne obremenjenosti verjetno niso odločili. Dodatno pomanjkljivost utegne predstavljati tudi pristranskost zaradi skupne metode (iz angl. common method bias), saj so podatki o vseh spremenljivkah pridobljeni prek samoocene (Podsakoff, MacKenzie, Lee in Podsakoff, 2003). Tveganje za tovrstno pomanjkljivost je sicer zmanjšano, ker smo pri vprašalnikih delno uporabili različne oblike ocenjevalnih lestvic. Iz korelacijske tabele pa je hkrati razvidno, da višina korelacij med koncepti bistveno variira.

V nadaljnjih raziskavah bi bilo smiselno preveriti odnos med dejansko in zaznano delovno obremenjenostjo ter na tej osnovi bolj ciljno oblikovati ukrepe za pomoč učiteljem 
pri spoprijemanju z delovnimi obremenitvami. Smiselno bi bilo preučevati tudi specifične delovne obremenitve in njihov vpliv v okviru dela z UPP, analizirati, kateri so za učitelja najbolj stresni in obremenjujoči dejavniki pri delu z UPP, kaj so dejavniki učinkovite podpore na šoli pri delu z UPP ter kako jih vpeljati v naš šolski sistem. Tovrstno raziskovanje bi lahko pripomoglo k bolj uravnoteženemu šolskemu okolju, saj gre po eni strani za razvoj inkluzije in spodbujanja enakih možnosti za vse učence ter na drugi strani za skrb za primerno delovno okolje in obremenitve sodobnega učitelja. Menimo tudi, da bi bilo smiselno izvesti kvalitativno raziskavo o poglobljenem doživljanju stresa učiteljev, saj bi nam tovrstni podatki pokazali bolj celostno sliko preučevane problematike, na osnovi katere bi lažje oblikovali preventivni program proti izgorelosti pri delu z UPP.

\section{Literatura}

Avramidis, E., Bayliss, P. in Burden, R. (2000). Student teachers' attitudes towards the inclusion of children with special educational needs in the ordinary school. Teaching and Teacher Education, 16, 277-293.

Bakker, A. B. in Demerouti, E. (2007). The job demandsresources model: State of the art. Journal of Managerial Psychology, 22, 309-328.

Bakker, A. B., Demerouti, E., de Boer, E., in Schaufeli, W. B. (2003). Job demands and job resources as predictors of absence duration and frequency. Journal of Vocational Behavior, 62, 341-356.

Bakker, A. B., Demerouti, E. in Euwema, M. C. (2005). Job resources buffer the impact of job demands on burnout. Journal of Occupational Health Psychology, 10, 170-180.

Beattie, J., Jordan, L. in Algozzine, B. (2006). Making Inclusion Work. California: Sage, Corwin Press.

Bela knjiga o vzgoji in izobraževanju v Republiki Sloveniji (2011). Ur. J. Krek in M. Metljak. Ljubljana: Zavod za šolstvo.

Borg, M. G. in Riding, R. J. (1991). Occupational stress and satisfaction in teaching. British Educational Research Journal, 17, 263-281.

Boyar, S. L., Carr, J. C., Mosley, D. C., Jr., in Carson, C. M. (2007). The development and validation of scores on perceived work and family demand scales. Educational and Psychological Measurement, 67, $100-115$.

Burke, R. J. in Greenglass, E. (1995). A longitudinal study of psychological burnout in teachers. Human Relations, 48, 187-202.

Byrne, B.M. (2001). Structural equation modeling with AMOS: Basic concepts, applications, and programming. Mahwah, NJ: Erlbaum.

Chang, M. L. (2009). An appraisal perspective of teacher burnout: examining the emotional work of teachers. Educational Psychology Review, 21, 193-218.
Chaplain, R. P. (2008). Stress and psychological distress among trainee secondary teachers in England. Educational Psychology, 28, 195-209.

Cohen, S., Kamark, T. in Mermelstein, R. (1983). A global measure of percieved stress. Journal of Health and Social Behavior, 24, 385-396.

Coladarci, T. (1992). Teachers' sense of efficacy and commitment to teaching. Journal of Experimental Education, 60, 323-337.

Darling-Hammond, L. (2001). The challenge of staffing in our schools. Educational Leadership, 58, 12-18.

Demerouti, E., Bakker, A. B., Nachreiner, F. in Schaufeli, W. B. (2001). The job demands - resources model of burnout. Journal of Applied Psychology, 86, 499-512.

Depolli Steiner, K. (2010). Stres in izgorelost učiteljev $v$ odnosu do njihovih pedagoških prepričanj in pričakovanj. (Neobjavljena doktorska disertacija). Ljubljana: Oddelek za psihologijo Filozofske fakultete Univerze v Ljubljani.

Depolli Steiner, K. (2011a). Analiza izvorov stresa osnovnošolskih učiteljev. Psihološka obzorja, 20, 121-138.

Depolli Steiner, K. (2011b). Izgorelost osnovnošolskih učiteljev. Vzgoja in izobraževanje, 42, 27-32.

DeVellis, R. F. (2003). Scale development: Theory and applications $\left(2^{\text {nd }}\right.$ ed.). Thousand Oaks, CA: Sage.

DuPaul, G.J., Gormley, M. J., Laracy, S.D. (2013). Comorbidity of LD and ADHD: implications of DSM5 for assessment and treatment. Journal of Learning Disabilities, 46, 43-51.

Friedman, I. A. (1991). High- and low-burnout schools: School culture aspects of teacher burnout. Journal of Educational Research, 84, 325-333.

Hakanen, J. J., Bakker, A. B. in Schaufeli, W. B. (2006). Burnout and work engagement among teachers. Journal of School Psychology, 43, 495-513.

Horne, M. D. in Ricciardo, J. L. (1988). Hierarchy of responds to handicaps. Psychological Reports, 62, 83-86.

Hayton, J. C., Allen, D. G. in Scarpello, V. (2004). Factor retention decisions in exploratory factor analysis: A tutorial on parallel analysis. Organizational Research Methods, 7, 191-205.

Jepson, E. in Forrest, S. (2006). Individual contributory factors in teacher stress: The role of achievement striving and occupational commitment. British Journal of Educational Psychology, 76, 183-197.

Karasek, R. A., Brisson, C., Kawakami, N., Houtman, I., Bongers, P. in Amick, B. (1998). The Job Content Questionnaire(JCQ):Aninstrumentforinternationally comparative assessment of psychosocial job characteristics. Journal of Occupational Health Psychology, 3, 322-355.

Kavkler, M. in Magajna L. (2008). Učne težave kot posebne vzgojno izobraževalne potrebe - opredelitev, razsežnost in podskupine učnih težav. V L. Magajna, S. Pečjak, C. Peklaj, G. Čačinovič Vogrinčič, K. 
Bregar Golobič, M. Kavkler in S. Tancig (Ur.). Učne težave $v$ osnovni šoli, problemi, perspektive, priporočila (str. 23-31). Ljubljana: Zavod Republike Slovenije za šolstvo.

Kavkler, M., Magajna, L., Lipec Stopar, M, Bregar Golobič, K, Čačinovič Vogrinčič, G. in Janželj, L. (2010). Težave dijakov pri učenju v poklicnem in strokovnem izobraževanju: opredelitev, prepoznavanje, oblike in mreža pomoči - raziskovalno poročilo. Ljubljana: CPI

Kobolt, A. in Žorga, S. (2013). Supervizija: proces razvoja in učenja v poklicu. Ljubljana: Pedagoška fakulteta Univerze v Ljubljani.

Kovšca, A. in Barle Lakota, A. (2010). Razlogi in predlogi sprememb Zakona o usmerjanju otrok s posebnimi potrebami na podlagi javne razprave. Šolsko svetovalno delo, 14, 4-11.

Kyriacou, C. (1987). Teacher stress and burnout: an international review. Educational Research, 29, 146-152.

Larhoven, T., Munk, D., Lynch, K., Bosma, J. in Rouse, J. (2007). A model for preparing special and general education preseervice teachers for unclusive education. Journal of Teacher Education, 58, 440-455.

Lazarus, R. S., in Folkman, S. (1984). Stress, appraisal, and coping. New York, NY: Springer.

Lee, R. T. in Ashforth, B. E. (1996). A meta-analitic examination of the correlates of the three dimensions of job burnout. Journal of Applied Psychology, 81, $123-133$.

Lerner, J. (2003). Learning disabilites. Theories, Diagnosis and Teaching Strategies. Boston: Northeastern Illinois University.

Magajna, L., Pečjak, S., Peklaj, C., Čačinovič Vogrinčič, G., Bregar Golobič, K., Kavkler, M. in Tancig, S. (2008). Učne težave $v$ osnovni šoli, problemi, perspektive, priporočila. Ljubljana: Zavod Republike Slovenije za šolstvo.

Martinez, R. (2003). Impact of graduate class on attitudes towards inclusion, percieved teaching efficacy and knowledge about adapting instruction for children with disabilites in inclusive settings. Teacher Development, 7, 473-494.

Maslach, C., Jackson, S.E. in Leiter, M.P. (1996). Maslach Burnout Inventory: Manual (3rd Ed.). Palo Alto, CA: Consulting Psychologist Press.

Maslach, C., Schaufeli, W.B. in Leiter, M.P. (2001). Job burnout. Annual Review of Psychology, 52, 397-422.

McCarthy, C. J., in Lambert, R. G. (2006). Helping teachers balance demands and resources in an era of accountability. V R. Lambert and C. McCarthy (Ur.), Understanding teacher stress in an age of accountability (str. 215-226). Greenwich, CT: Information Age Publishing.

Morgan, E. S., Umberson, K., \& Hertzog, C. (2013). Construct validation of self-reported stress scales. Psychological Assessment, 26, 90-99.
Opara B., Barle Lakota, A., Globačnik, B., Kobal Grum, D., Košir, S., Macedoni Lukšič, M, ... Klavžar, K. (2010). Analiza vzgoje in izobraževanja otrok s posebnimi potrebami v Sloveniji. Ljubljana: Pedagoški inštitut.

Peklaj, C., Kalin, J., Pečjak, S., Puklek Levpušček, M., Valenčič Zuljan, M. in Ajdišek, N. (2009). Učiteljske kompetence in doseganje vzgojno-izobraževalnih ciljev $v$ šoli. Ljubljana: Filozofska fakulteta.

Podsakoff, P. M., MacKenzie, S. B., Lee, J. Y. in Podsakoff, N. P. (2003). Common method biases in behavioral research: A critical review of the literature and recommended remedies. Journal of Applied Psychology, 88, 879-903.

Pretnar, T. (2012). Medkulturna analiza stališč učiteljev do inkluzije otrok s posebnimi potrebami. (Neobjavljena doktorska disertacija). Ljubljana: Pedagoška fakulteta Univerze v Ljubljani.

Quint, J., Bloom, H. S., Black, A. R., Stephens, L. in Akey, T. M. (2005). The Challenge of Scaling up Educational Reform, Findings and Lessons from First Things First, Final Report. New York: MDRC.

Reeve, J. (2002). Self-determination theory applied to educational settings. V E. L. Deci in R. M. Ryan (ur.), Handbook of self-determination research (str. 183203). Rochester, NY: University of Rochester Press.

Regent, P. (2013). Obremenjenost in zadovoljstvo pri delu v odnosu do izgorelosti učiteljev. (Neobjavljena doktorska disertacija). Ljubljana: Oddelek za psihologijo Filozofske fakultete Univerze v Ljubljani.

Resman, M. (2003). Integracija/inkluzija med zamislijo in uresničevanjem. Sodobna pedagogika, 54, 64-83.

Rosenholtz, S. J. in Simpson, C. (1990). Workplace conditions and the rise and fall of teachers' commitment. Sociology of Education, 63, 241- 257.

Rutar Ilc, Z., Tacer, B. in Žarkovič Adlešič (2014). Kolegialni coaching. Priročnik za strokovni in osebnostni razvoj. Ljubljana: Zavod za šolstvo RS.

Ryan, R. M., Conell, J.P. in Deci, E. L. (1985). A motivational analysis of self-determination and selfregulation in education. V C. Ames in R.E. Ames (ur.), Research on motivation in education: The clasroom millieu (str. 13-51). New York: Academic.

San Miguel, S. K., Forness, S. R., Kavale, K. A. (1996). Social skills deficits in learning disabilities: The psychiatric comorbidity hypotesis. Learning Disability Quarterly, 19, 252-261.

Schaufeli, W. B. in Enzmann, D. (1998). The burnout companion to research and practice: A critical analysis. London: Taylor \& Francis.

Schmidt, M. (2001). Socialna integracija otrok s posebnimi potrebami v osnovno šolo. Maribor: Pedagoška fakulteta Univerze v Mariboru.

Schmidt, M. in Čagran, B. (2011). Stališča slovenskih učiteljev o vplivu integracije/inkluzije na učence $\mathrm{z}$ različnimi vrstami posebnih potreb v osnovni šoli. Šolsko polje, 22, 55-72.

Scruggs, T. E. in Mastropieri, M. A. (1996). Teacher perceptions of mainstreaming-inclusion, 1958-1995: 
A research synthesis. Exceptional Children, 63, 59-74.

Shoemaker, D.J. (1996). Theories of deliquency. New York: Oxford Universitiy Press.

Siqueira Reis, R., Ferreira Hino, A. A., in Rodriguez Añez, C. R. (2010). Perceived Stress Scale: Reliability and Validity Study in Brazil. Journal of Health Psychology, 15, 107-114.

Skaalvik, E. M. in Skaalvik, S. (2009). Does school context matter? Relations with teacher burnout and job satisfaction. Teaching and Teacher Education, 25, 518-524.

Skaalvik, E. M. in Skaalvik, S. (2011). Teacher job satisfaction and motivation to leave the teaching profession: Relations with school context, feeling of belonging, and emotional exhaustion. Teaching and Teacher Education, 27, 1029-1038.

Slivar, B. (2009). Raziskava o poklicnem stresu pri slovenskih vzgojiteljih in učiteljih: povzetek. Ljubljana: SVIZ Sindikat vzgoje, izobraževanja, znanosti in kulture Slovenije.

Slivar, B.(2013). Na poti k dobremu počutju: obvladovanje stresa v šoli - teoretični vidik: knjiga za ravnatelje in učitelje o obvladovanju stresa na ravni šole in na ravni posameznika. Ljubljana: Zavod RS za šolstvo.

Smith, T. M. in Ingersoll, R. M. (2004). What are the effects of induction and mentoring on beginning teacher turnover? American Educational Research Journal, 41, 681-714.

Stempien, L. R. in Loeb, R. C. (2002). Differences in job satisfaction between general education and special education teachers. Implications for Retention. Remedial and Special Education, 23, 258-267.

Stoeber, J. in Rennert, D. (2008). Perfectionism in school teachers: relations with stress appraisals, coping styles, and burnout. Anxiety, Stress, \& Coping, 21, $37-53$.

Tement, S. in Korunka, C. (2013). Does trait affectivity predict work-to-family conflict and enrichment beyond job characteristics? Journal of Psychology: Interdisciplinary and Applied, 147, 197-216.

Tement, S., Korunka, C. in Pfifer, A. (2010). Toward the assessment of the work-family interface: Validation of the Slovenian versions of work-family conflict and work-family enrichment scales. Psihološka obzorja [Horizons of Psychology], 19, 53-74.

Travers, C. J. in Cooper, C. L. (1993). Mental health, job satisfaction and occupational stress among UK teachers. Work and Stress, 7, 203-219.

Yagil, D. (1998). If anything can go wrong it will: occupational stress among inexpirienced teachers. International Journal of Stress Management, 15, 179-188.

Viola, S. G. (2008). Zadovoljevanje socialnih in čustvenih potreb učencev s posebnimi potrebami v inkluzivnem okolju. V M. Kavkler, A. M. Clement, M. Košak Babuder, S. Puler Lah in S. G. Viola (Ur.). Razvoj inkluzivne vzgoje in izobraževanja - izbrana poglavja $v$ pomoč šolskim timom (str. 153-165). Ljubljana: Zavod Republike Slovenije za šolstvo.
Zakon o financiranju vzgoje in izobraževanja (2007). Uradni list RS, št. 16/07.

Zakon o usmerjanju otrok s posebnimi potrebami (2000). Uradni list RS, št. 54/00.

Zakon o usmerjanju otrok s posebnimi potrebami (2011). Uradni list RS, št. 58/2011. 


\section{Priloga}

Tabela 4. Faktorske nasičenosti postavk Vprašalnika o specifičnih značilnostih delovnega mesta, vezanih na delo z UPP

\begin{tabular}{|c|c|c|c|c|c|}
\hline & & \multicolumn{4}{|c|}{ Nasičenosti } \\
\hline & & $\begin{array}{c}\text { Zadovoljstvo } \\
\text { učiteljev s } \\
\text { splošnim } \\
\text { sistemom } \\
\text { strokovne } \\
\text { podpore }\end{array}$ & $\begin{array}{c}\text { Delovna } \\
\text { obremenitev z } \\
\text { UPP }\end{array}$ & $\begin{array}{l}\text { Zaznana lastna } \\
\text { kompetentnost } \\
\text { pri delu z UPP }\end{array}$ & $\begin{array}{l}\text { Opora pri delu z } \\
\text { UPP na šoli }\end{array}$ \\
\hline & $\begin{array}{l}\text { Delo z UPP je dovolj načrtno in } \\
\text { sistematično. }\end{array}$ &, 47 &, 10 & 09 &, 27 \\
\hline 2. & $\begin{array}{l}\text { Dovolj je strokovne podpore na šoli za } \\
\text { delo z UPP. }\end{array}$ &, 58 &,- 01 &, 18 &, 17 \\
\hline 3. & $\begin{array}{l}\text { Dovolj je strokovne podpore zunanjih } \\
\text { ustanov za delo z UPP. }\end{array}$ &, 60 &,- 10 &, 14 &,- 09 \\
\hline 4. & $\begin{array}{l}\text { Dovolj je strokovnega kadra za delo z } \\
\text { UPP. }\end{array}$ &, 51 &,- 03 & ,07 &,- 04 \\
\hline 5. & $\begin{array}{l}\text { Zadovoljen/-a sem z utečeno prakso nu- } \\
\text { denja pomoči UPP. }\end{array}$ &, 44 &,- 09 & ,24 & ,18 \\
\hline 6. & $\begin{array}{l}\text { Preveč je dodatnega dela in sestankov s } \\
\text { strokovnim timom glede UPP. }\end{array}$ &, 05 & ,70 &,- 04 &,- 03 \\
\hline & $\begin{array}{l}\text { Priprava didaktičnih pripomočkov za UPP } \\
\text { mi vzame preveč časa. }\end{array}$ &, 01 & ,68 &,- 03 & 05 \\
\hline 8. & $\begin{array}{l}\text { Preveč časa moram namenjati pisanju in } \\
\text { urejanju dokumentacije za UPP. }\end{array}$ &,- 05 & ,69 &, 13 &,- 04 \\
\hline & $\begin{array}{l}\text { Razrednik ima preveč dodatnih obremeni- } \\
\text { tev, če so v razredu UPP. }\end{array}$ &,- 04 & ,66 &, 02 &,- 03 \\
\hline & $\begin{array}{l}\text { Učitelji smo preobremenjeni s } \\
\text { poučevanjem UPP. }\end{array}$ &,- 02 & ,66 &,- 10 &, 02 \\
\hline & $\begin{array}{l}\text { Usklajevanje urnikov z drugimi strokovn- } \\
\text { jaki, ki delajo z UPP, je težko. }\end{array}$ &,- 03 & ,41 &, 00 & 01 \\
\hline & $\begin{array}{l}\text { Imam dovolj strokovnega znanja za delo z } \\
\text { UPP. }\end{array}$ & ,22 &,- 10 & ,61 &,- 16 \\
\hline & Pri poučevanju UPP sem uspešen/-na. &,- 00 &, 10 &, 74 &, 01 \\
\hline & $\begin{array}{l}\text { Pri premagovanju težav pri delu z UPP } \\
\text { sem uspešen/-a. }\end{array}$ &,- 06 & 04 & ,76 & ,09 \\
\hline & Izvajanje prilagoditev za UPP mi ni težko. &, 04 &,- 30 & ,40 &, 00 \\
\hline & $\begin{array}{l}\text { Podpore specialnega pedagoga pri delu } \mathrm{z} \\
\text { UPP je premalo. (obratno vrednotenje) }\end{array}$ & ,27 &,- 21 &,- 07 & ,35 \\
\hline & $\begin{array}{l}\text { Ne čutim podpore s strani vodstva pri delu } \\
\text { z UPP. (obratno vrednotenje) }\end{array}$ & ,02 &,- 08 &, 11 & ,60 \\
\hline & $\begin{array}{l}\text { K nudenju pomoči UPP na naši šoli pris- } \\
\text { topamo prepozno. (obratno vrednotenje) }\end{array}$ & ,23 & ,07 &,- 06 & ,45 \\
\hline & $\begin{array}{l}\text { Delu z UPP na naši šoli se namenja dovolj } \\
\text { pozornosti in dovolj časa. }\end{array}$ &, 32 & 19 & ,13 & ,38 \\
\hline
\end{tabular}

Tabela 5. Korelacije med faktorji Vprašalnika o specifičnih značilnostih delovnega mesta, vezanih na delo z UPP

\begin{tabular}{lrrr}
\hline & 1 & 2 & 3 \\
\hline 1. Zadovoljstvo učitelja s splošnim sistemom strokovne podpore za UPP & $/$ & & \\
2. Delovna obremenitev z UPP &,- 14 & $/$ & 4 \\
3. Kompetentnost učitelja pri delu z UPP &, 33 &,- 27 & $/$ \\
4. Opora pri delu z UPP na šoli &, 30 &,- 31 &, 29 \\
\hline
\end{tabular}

